\section{Pengaruh Kebijakan E-Filing, Sanksi Perpajakan dan Kesadaran Wajib Pajak Terhadap Kepatuhan Wajib Pajak Orang Pribadi}

\author{
Supriatiningsih dan Firhan Saefta Jamil \\ STIE Muhammadiyah Jakarta \\ EMail : nining1975@yahoo.com dan,firhanseafa@gmail.com
}

Taxpayer

Compliance and

Tax Policies

\section{ABSTRACT}

The e-filing policy is made to make it easier for individual taxpayers to report their tax returns, tax sanctions that will pressureindividual taxpayers to continue to comply, and awareness of taxpayers also needs to be increased because of awareness of taxpayers. The population used in this study is the Individual Taxpayer registered at the Setiabudi Tax Office IV. In this study using the Probability sampling method with a simple random sampling type. The data source in this study is the taxpayer as the respondent chosen randomly. This research is using Primary data needed is data related to the variables use, with 112 respondens.. This study uses the partial least squale (PLS). The test results show that e-filing policy has a positive effect on taxpayer compliance, the existence of the E-Filing Policy makes it easier for individual taxpayers to report their SPT annually and saves time, cost and effort Tax Sanction has a negative effect on Taxpayer Compliance, there are still many individual taxpayers who ignore the existence of tax sanctions and there are still many taxpayers who are given sanctions for not reporting their SPT on time and Taxpayer Awareness has an effect on Taxpayer Compliance. that the awareness of individual taxpayers, the higher the understanding and implementation of tax obligations, thereby increasing compliance. From the results obtained efiling policy variables and Taxpayer Awareness have a positive effect on the compliance of individual taxpayers

Keywords: E-Filing Policy, Tax Sanctions, Taxpayer Awareness, Taxpayer Compliance

\begin{abstract}
ABSTRAK
Kebijakan e-filing dibuat untuk memudahkan wajib pajak orang pribadi melaporkan SPT nya, sanksi perpajakan yang akan menekan wajib pajak orang pribadi untuk terus patuh, dan kesadaran wajib pajak juga perlu ditingkatkan karna dengan adanya kesadaran wajib pajak orang pribadi, Pada penelitian ini menggunakan metode Probability sampling dengan jenis simple random sampling. Sumber data dalam penelitian ini yaitu wajib pajak orang pribadi sebagai responden yang dipilih secara acak. Penelitian deskriptif kuantitatif untuk menggambarkan data data perhitungan yang diperoleh, dengan jumlah responden 112. Penelitian ini menggunakan Model Partial Least Square (PLS). Tujuan Penelitian bertujuan untuk menguji kebijakan e-filing, sanksi perpajakan dan kesadaran wajib pajak terhadap kepatuhan wajib pajak orang pribadi. Populasi yang digunakan dalam penelitian ini adalah Wajib Pajak Orang Pribadi yang terdaftar di Kantor Pajak Setiabudi IV. Hasil pengujian menunjukkan bahwa Kebijakan e-filing berpengaruh positif terhadap kepatuhan wajib pajak orang pribadi, dengan adanya Kebijakan E-Filing memudahkan Wajib Pajak orang pribadi untuk melaporkan SPT setiap tahun nya dan lebih menghemat waktu, biaya, serta tenaga Sanksi Perpajakan berpengaruh negatif terhadap Kepatuhan Wajib Pajak orang pribadi, masih banyak Wajib Pajak yang menghiraukan adanya Sanksi Perpajakan dan masih banyak Wajib Pajak yang diberikan Sanksi karna tidak Melaporkan SPT tepat waktu. dan Kesadaran Wajib Pajak berpengaruh terhadap Kepatuhan Wajib Pajak orang pribadi, bahwa kesadaran wajib pajak orang pribadi semakin tinggi maka pamahaman dan pelaksanaan kewajiban perpajakan semakin baik sehingga meningkatkan kepatuhan. Dari hasil yang didapat
\end{abstract}

Submitted: MARET 2021

Accepted: APRIL 2021

\title{
JIAKES
}


Taxpayer

Compliance and

Tax Policies

variabel Kebijakan e-filing dan Kesadaran Wajib Pajak orang pribadi berpengaruh positif terhadap Kepatuhan Wajib Pajak Orang Pribadi.

Kata Kunci : kebijakan e-filing, sanksi perpajakan, kesadaran, kepatuhan, wajib pajak

\section{PENDAHULUAN}

Tercapainya rencana penerimaan pajak sangat ditentukan oleh peran serta wajib Pajak baik badan maupun orang pribadi dalam sistem pemungutan pajak. Penerimaan pendapatan dari pajak yang optimal dapat dilihat dari berimbangnya tingkat penerimaan pajak aktual dengan penerimaan pajak potensial atau tidak terjadi tax gap. Menurut James yang dikutip oleh Gunadi (2009:4) menyatakan bahwa Besarnya tax gap mencerminkan tingkat kepatuhan membayar pajak (tax compliance). Oleh karena itu, faktor utama yang mempengaruhi realisasi penerimaan pajak adalah kepatuhan Wajib Pajak. Kepatuhan yang dimaksudkan merupakan istilah tingkat sampai dimana Wajib Pajak mematuhi undang-Undang perpajakan dan memenuhi bidang perpajakan. Contoh jika Wajib Pajak baik badan maupun wajob pajak orang pribadi membayar dan melaporkan pajak terutangnya tepat waktu, maka Wajib Pajak orang pribadi tersebut dapat dianggap patuh. Tabel 11 Realisasi Penerimaan Pajak Tahun 2015-2019

\begin{tabular}{|c|c|c|c|c|}
\hline No & Tahun & Target & Realisasi & Capaian \\
\hline $\mathbf{1}$ & 2015 & $100 \%$ & $81,97 \%$ & $81,97 \%$ \\
\hline $\mathbf{2}$ & 2016 & $100 \%$ & $81,60 \%$ & $81,60 \%$ \\
\hline $\mathbf{3}$ & 2017 & $100 \%$ & $89,68 \%$ & $89,68 \%$ \\
\hline $\mathbf{4}$ & 2018 & $100 \%$ & $92,24 \%$ & $92,24 \%$ \\
\hline $\mathbf{5}$ & Per Oktober 2019 & $100 \%$ & $64,56 \%$ & $64,56 \%$ \\
\hline
\end{tabular}

Sumber: Laporan Kinerja DJP 2015-2019

Menurut Susanto (2013) kepatuhan wajib pajak dapat dipengaruhi oleh dua jenis faktor yaitu faktor internal dan faktor eksternal. Faktor internal merupakan faktor yang berasal dari wajib pajak sendiri dan berhubungan dengan karakteristik individu yang menjadi pemicu dalam menjalankan kewajiban perpajakannya. Faktor internal yang mempengaruhi kepatuhan wajib pajak adalah faktor pendidikan, faktor kesadaran keberagaman, faktor kesadaran perpajakan, faktor pemahaman terhadap undang-undang dan peraturan perpajakan dan faktor rasional. Berbeda dengan faktor internal, faktor eksternal adalah faktor yang berasal dari luar diri wajib pajak, seperti situasi dan lingkungan di sekitar wajib pajak.

Untuk mendukung kepatuhan wajib pajak, Pemerintah memberikan fasilitas pelayanan elektronik salah satunya adalah E-filling. Fasilitas E-Filing merupakan layanan pengisian dan penyampaian Surat Pemberitahuan Wajib Pajak yang dilakukan secara elektronik melalui system online yang real time kepada Direktorak Jenderal Pajak melalui internet pada website Direktur Jenderal Pajak atau Penyedia Jasa Aplikasi yang telah ditunjuk oleh Direktorat Jenderal Pajak. Dengan diterapkannya sistem e-filing, diharapkan dapat memberikan kenyamanan dan kemudahan bagi Wajib Pajak dalam mempersiapkan dan menyampaikan SPT karena dapat dikirimkan kapan saja dan dimana saja sehingga dapat meminimalkan biaya dan waktu yang digunakan Wajib Pajak untuk memperhitungan, pengisian, sekaligus penyampaian SPT. E-Filing dapat meminimalkan biaya dan waktu karena hanya dengan menggunakan komputer yang terhubung internet, penyampaian SPT dapat dilakukan kapan saja yaitu selam 24 jam sehari dan 7 hari dalam seminggu (termasuk hari libur) dan dimana saja tanpa perlu datang ke kantor pajak untuk memberikannya kepada petugas pajak.

Penyampaian SPT melalui pelayanan e-filing atau e-SPT pertama kali diatur dengan keputusan dirjen pajak melalui KEP- 05/PJ./2005 tentang tata cara penyampaian Surat Pemberitahuan secara elektronik (e-filing) melalui Perusahaan Penyedia Jasa Aplikasi (ASP). Adapun beberapa Perusahaan Penyedia Jasa Aplikasi (ASP). Selain 2 (dua) jenis SPT Tahunan WP OP 1770 S dan 1770 S, untuk jenis SPT lainnya dilaporkan melalui 
Penyedia Jasa Aplikasi (Application Service Provider-ASP) yang telah ditunjuk oleh Dirketorat Jenderal Pajak.

Dalam hal ini penulis menemukan hasil penelitian yang dilakukan oleh Suherman, Almunawaroh, dan Marliana (2015) menunjukkan bahwa e-filing berpengaruh signifikan terhadap kepatuhan Wajib Pajak, sedangkan hasil penelitian yang dilakukan oleh Rosyida (2014) menunjukkan bahwa e-filing tidak berpengaruh terhadap kepatuhan Wajib Pajak. Hasil penelitian Rusmadi (2017) mengenai sanksi perpajakan menunjukkan bahwa sanksi perpajakan berpengaruh positif terhadap kepatuhan wajib pajak. Sanksi pajak mampu membuat penerimaan negara meningkat drastis. Hal tersebut didukung oleh penelitian Ngadiman \& Huslin (2015) bahwa sanksi pajak berpengaruh positif terhadap kepatuhan wajib pajak. Hal tersebut tidak sesuai dengan penelitian Winerungan (2017) yang menyatakan sanksi pajak berpengaruh negatif terhadap kepatuhan wajib pajak. Hasil Penelitian yang dilakukan oleh Suharyono (2019) mengatakan bahwa kesadaran Wajib Pajak tidak berpengaruh terhadap kepatuhan Wajib Pajak.

Definisi pajak menurut Undang-undang Nomor 28 Tahun 2007 tentang Ketentuan Umum dan Tata Cara Perpajakan (UU KUP) yaitu: "Pajak adalah kontribusi wajib kepada negara yang terutang oleh orang pribadi atau badan yang bersifat memaksa berdasarkan Undang-Undang, dengan tidak medapatkan imbalan secara langsung dan digunakan untuk keperulan negara bagi sebesar-besarnya kemakmuran rakyat."

E-Filing adalah cara penyampaian Surat Pemberitahuan (SPT) secara elektronik yang dilakukan secara online dan real time melalui internet pada website Direktorat Jenderal Pajak (http://www.pajak.go.id) atau Penyedia Layanan SPT Elektronik atau Application Service Provider (ASP) (Direktorat Jenderal Pajak, n.d.). E-Filing pajak merupakan suatu bentuk pengadopsian teknologi yang dilakukan pemerintah khususnya Direktorat Jenderal Pajak dalam hal administrasi perpajakan guna meningkatkan pelayanan kepada Wajib Pajak dalam penyampaian Surat Pemberitahuan.

Sanksi perpajakan merupakan jaminan ketentuan peraturan perundang-undangan perpajakan (norma perpajakan) akan ditaati/dipatuhi. Atau bisa dengan kata lain sanksi perpajakan merupakan alat pencegah (preventif) agar Wajib Pajak tidak melanggar kebijakan perpajakan. Dalam undang- undang perpajakan dikenal dua macam sanksi, yaitu Sanksi Administrasi dan Sanksi Pidana. Ancaman terhadap pelanggaran norma perpajakan ada yang diancam dengan sanksi administrasi saja, ada yang diancam dengan sanksi pidana saja, dan ada pula yang diancam dengan sanksiadministrasi dan sanksi pidana. Pada hakikatnya, pengenaan sanksi perpajakan diberlakukan untuk menciptakan kepatuhan Wajib Pajak melaksanakan kewajiban perpajakan. Menurut Mardiasmo (2011 : 59), sanksi administrasi merupakan pembayaran kerugian kepada Negara, khususnya yang berupa bunga dan kenaikan. Menurut Sutedi (2011 : 221), sanksi administrasi berupa denda dikenakan terhadap pelanggaran peraturan yang bersifat hukum publik. Sanksi administrasi merupakan pembayaran kerugian terhadap negara yang berupa denda administrasi, bunga, atau kenaikan pajak yang terutang. Sanksi administrasi ditekankan kepada pelanggaran-pelanggaran administrasi perpajakan yang tidak mengarah kepada tindak pidana perpajakan (Purwono : $2010 ; 68$ ). Sanksi administrasi terdiri atas tiga macam, yaitu sanksi administrasi berupa denda, sanksi administrasi berupa bunga, sanksi administrasi berupa kenaikan.

Kesadaran wajib pajak merupakan kondisi pajak yang mengetahui, mengakui menghargai dan menaati ketentuan perpajakan yang berlaku serta memiliki kesungguhan serta keinginan memenuhi kewajiban pajaknya. Kesadaran wajib pajak dalam membayar pajak merupakan perilaku wajib pajak berupa pandangan atau perasaan yang melibatkan pengetahuan, keyakinan dan penalaran disertai kecenderungan untuk bertindak sesuai yang diberikan oleh sistem dan ketentuan pajak tersebut (fikriningrum 2012). Dalam hal ini kesadaran wajib pajak orang pribadi sangat minim di Indonesia, banyak wajib pajak orang pribadi yang ragu melaporkan sebagian hasil yang didapatkan oleh wajib pajak. Kepatuhan Wajib Pajak. Pengertian Wajib Pajak menurut Undang-Undang Nomor 16 Tahun 2009, Pasal 1 angka 2 tentang Ketentuan Umum dan Tata Cara Perpajakan (KUP) berbunyi : "Wajib Pajak adalah orang pribadi atau badan, meliputi pembayar pajak, 
Taxpayer

Compliance and

Tax Policies

202 pemotong pajak, dan pemungut pajak, yang mempunyai hak dan kewajiban perpajakan sesuai dengan ketentuan peraturan perundang-undangan perpajakan." Menurut Soemitro (2004) Wajib Pajak merupakan subjek pajak yang memenuhi syarat-syarat objektif, jadi memenuhi tabestand yang ditentukan oleh undang-undang, yaitu dalam rangka UU PPh 1984, menerima atau memperoleh penghasilan kena pajak, yaitu penghasilan yang melebihi pendapatan tidak kena pajak bagi wajib pajak dalam negeri. Subjek pajak adalah orang atau badan yang berkedudukan di Indonesia. Obyek pajak merupakan setiap tambahan ekonomis yang diperoleh oleh Wajib Pajak untuk konsumsi maupun untuk menambah kekayaan Wajib Pajak tersebut.

\section{Pengembangan Hipotesis}

Pengaruh Kebijakan E-Filing terhadap Kepatuhan Wajib Pajak orang pribadi.. EFiling merupakan sistem yang dibuat untuk mendukung terselenggaranya good governance, sesuai dengan tujuan modernisasi perpajakan. Sistem e-Filing dirancang untuk mengurangi dan menghilangkan interaksi langsung antara wajib pajak dengan aparatur pajak sehingga potensi terjadinya Korupsi Kolusi dan Nepotisme (KKN) dapat dicegah. E-Filing dapat meminimalkan biaya dan waktu karena hanya dengan menggunakan komputer yang terhubung internet, penyampaian SPT dapat dilakukan kapan saja yaitu selam 24 jam sehari dan 7 hari dalam seminggu (termasuk hari libur) dan dimana saja tanpa perlu datang ke kantor pajak untuk memberikannya kepada petugas pajak. Hal ini sesuai dengan hasil penelitian dari Nurlaela (2018) dan Agustiningsih, Isroah (2016) bahwa penerapan E-Filling berpengaruh positif terhadap kepatuhan wajib.

Hipotesis 1 : Kebijakan E-Filling berpengaruh terhadap kepatuhan wajib pajak orang pribadi.

Pengaruh sanksi perpajakan terhadap kepatuhan wajib pajak orang pribadi. Sanksi pajak dikenakan pada seorang wajib pajak bila melakukan keterlambatan atau pelanggaran. Seperti yang telah dijabarkan sebelumnya, ada dua macam sanksi dalam pajak yaitu sanksi administrasi dan sanksi pidana. Sanksi administrasi adalah sanksi yang dikenakan dengan melakukan pembayaran kerugian finansial pada negara karena pelaksanaan ketentuan peraturan perundang - undangan tidak sebagaimana mestinya. Sedangkan sanksi pidana merupakan siksaan atau penderitaan dan benteng hukum agar norma perpajakan dipatuhi. Diharapkan dengan adanya peraturan sanksi yang diterapkan tersebut dapat membuat wajib pajak orang pribadi semakin patuh dalam memenuhi kewajiban pajaknya. Dalam penelitian yang dilakukan oleh Dina (2015) menyatakan bahwa sanksi pajak berpengaruh positif terhadap kepatuhan wajib pajak dapat diterima. Artinya semakin berat dan efektif sanksi pajak yang diterapkan, semakin tinggi kepatuhan wajib pajak. Semakin tinggi sanksi yang dikenakan maka semakin tinggi pula kepatuhan pajak. Hasil ini juga sejalan dengan hasil penelitian dari Tryana (2015) dan Nurlis (2015) bahwa sanksi berpengaruh positif dan signifikan terhadap kepatuhan wajib pajak. Hipotesis 2 : Sanksi Perpajakan berpengaruh positif terhadap kepatuhan wajib Pajak orang pribadi.

Pengaruh Kesadaran wajib pajak terhadap kepatuhan wajib pajak orang pribadi. Menurut Sapriadi (2013) dan Setiawan (2014), menyatakan bahwa kesadaran wajib pajak berpengaruh positif terhadap kepatuhan wajib pajak. Kesadaran wajib pajak akan perpajakan adalah rasa yang timbul dari dalam diri Wajib Pajak atas kewajibannya membayar pajak dengan ikhlas tanpa adanya paksaan. Dengan kesadaran pajak yang tinggi, kepatuhan wajib pajak terhadap kewajiban pajaknya dapat meningkat. Hal tersebut sejalan dengan penelitian Suardana (2014) bahwa kesadaran Wajib Pajak memiliki pengaruh terhadap kepatuhan Wajib Pajak. Menurut Jatmiko (2016), kesadaran wajib pajak atas fungsi perpajakan sebagai pembiayaan negara sangat diperlukan untuk meningkatkan kepatuhan wajib pajak. Menurut Muliari dan Nugroho (2016) semakin tinggi tingkat kesadaran wajib pajak maka pamahaman dan pelaksanaan kewajiban perpajakan semakin baik sehingga dapat meningkatkan kepatuhan. Pentingnya suatu kesadaran untuk membayar pajak sangat diperlukan, mengingat tingginya kepentingan pajak bagi Negara diwajibkan bagi Wajib Pajak untuk sadar dalam membayar pajak. Jadi 
Semakin tinggi suatu kesadaran wajib pajak dalam membayar pajak, maka rasa kesadaran akan tinggi dalam mematuhi membayar pajak. Hipotesis 3 : Kesadaran wajib pajak berpengaruh positif terhadap kepatuhan wajib Pajak orang pribadi

\section{Kerangka Pemikiran}

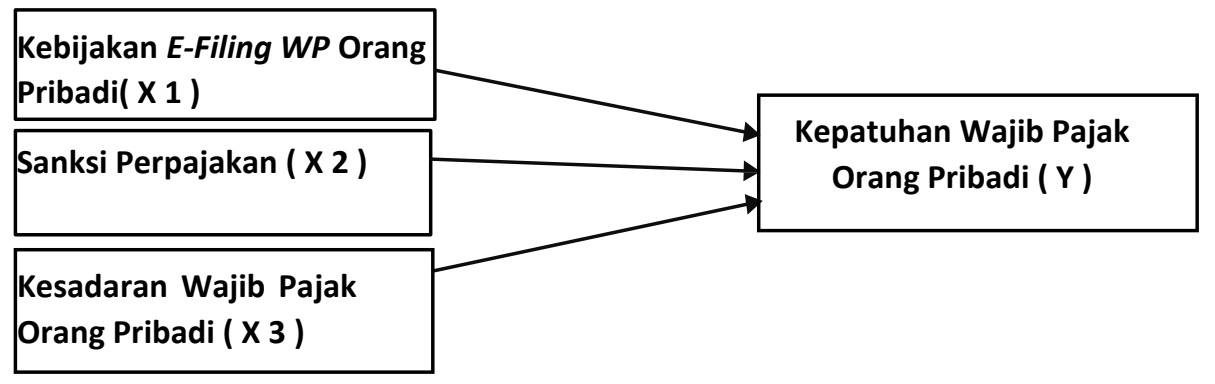

Gambar 1 Kerangka Pemikiran Penelitian

\section{Metodologi Penelitian}

Dalam penelitian ini, peneliti menggunakan metode penelitian kausal yang bertujuan untuk menguji hipotesis tentang pengaruh satu atau beberapa variabel (pengaruh kebijakan E-filling, sanksi perpajakan, kesadaran wajib pajak) terhadap variabel dependen (kepatuhan wajib pajak orang pribadi). Penelitian ini memerlukan pengujian hipotesis dengan uji statistika.Variabel-variabel yang diteliti berkenaan dengan topik pembahasan adalah: (1) Kebijakan E-filling wajib pajak orang pribadi sebagai variabel independent $\left(\mathrm{X}_{1}\right)$, (2) Sanksi perpajakan sebagai variabel independent $\left(\mathrm{X}_{2}\right)$, (3) Kesadaran wajip pajak orang pribadi sebagai variabel independent (X3), (4) Kepatuhan wajib Pajak orang pribadi sebagai variabel terikat atau dependent variable $(\mathrm{Y})$

Penelitian dilakukan pada Desember 2019 - Agustus 2020, di kantor pajak pratama Setiabudi IV, Tebet Jakarta Selatan. Populasi dalam penelitian ini adalah Wajib Pajak orang pribadi yang berada di wilayah KPP Pratama Setiabudi IV, Tebet Jakarta Selatan. Jumlah populasi Wajib Pajak orang pribadi sampai dengan bulan Desember 2019 adalah 58.752 orang. Untuk menentukan ukuran sampel minimal dari populasi terpilih, periset menggunakan tabel rumusan yang dikembangkan oleh Rea \& Parker dalam Fuad Mas'ud $(2004,82)$. Berdasarkan tabel rumusan tersebut, sampel yang diperlukan dari populasi 58,752 Wajib Pajak orang pribadi (WPOP) yang terdaftar sampai dengan bulan Desember 2019 di KPP Pratama Jakarta Setiabudi IV pada tingkat Keyakinan (confidence level) $95 \%$ dan dengan tingkat kesalahan (margin of error) 5\%; didapatkan ukuran sampel yang diperlukan/generalisasi populasi (n) sebanyak 97.

Rumus untuk melakukan penyesuaian n (yakni,n') adalah:

$$
n^{\prime}=\frac{n}{(e)(r)}
$$

Estimasi Ukuran Sampel Penelitian:

e $=90 \%$ Populasi target akan bersedia untuk mengisi kuesioner

$\mathrm{r}=$ Tingkat tanggapan $($ responden rate $)=$ sekitar $87 \%$

$$
N^{\prime}(\text { penyesuaian } n)=\quad \frac{97}{(90)(87)}=122,81
$$

Jadi, jumlah sampel yang diperoleh untuk memenuhi ukuran sampel minimal (n) adalah 123 sampel. Penelitian ini menggunakan teknik kuesioner dalam mengumpulkan data yang dibutuhkan. Teknik kuesioner adalah teknik pengumpulan data dengan cara menyebarkan daftar pertanyaan yang terdiri dari pertanyaan yang bersifat tertutup kepada responden karena telah disediakan alternatif jawaban yang mungkin dipilih sehingga responden merasa mudah dalam mengisi kuesioner. Adapun metode pengumpulan data yang digunakan oleh peneliti, yaitu urvai dengan kuesioner dan wawancara. Metode analisis data yang digunakan adalah Uji Validitas, Uji Reliabilitas, Koefisien Determinasi (R-Square), Hasil Penelitian T - Statistik. 
Taxpayer

Compliance and

Tax Policies

\section{4}

Peneliti menggunakan tiga variabel independen yaitu variabel kebijakan E-filling wajib pajak orang pribadi dan pengaruhnya terhadap kepatuhan wajib pajak orang pribadi, variabel sanksi perpajakan dan pengaruhya terhadap kepatuhan wajib pajak orang pribadi, variabel kesadaran wajib pajak orang pribadi dan pengaruhnya terhadap kepatuhan wajib pajak orang pribadi yang memadai untuk menguji hubungan dengan variabel dependen (kepatuhan wajib pajak orang pribadi). Untuk tujuan pada penelitian ini dapat menggunakan Model Partial Least Square (PLS) dibandingkan dengan AMOS, LISREL, dan software SEM. Tahapan-tahapan pengujian hipotesis 1 sampai dengan 3 adalah sebagai berikut: (1) Menyatakan hipotesis penelitian secara statistic, (2) Menentukan tingkat signifikansi (sebesar 5\%), (3) Menentukan kriteria penerimaan atau penolakan hipotesis. Jika p-value $>0,05$ maka $\mathrm{H}_{0}$ diterima dan $\mathrm{H}_{\mathrm{a}}$ ditolak dan Jika $\mathrm{p}$ value $\leq 0,05$ maka $\mathrm{H}_{0}$ ditolak dan $\mathrm{H}_{\mathrm{a}}$ diterima, (4) Menarik simpulan

\section{HASIL DAN PEMBAHASAN}

Dalam penelitian ini responden yang digunakan adalah responden yang telah memiliki Nomor Pokok Wajib Pajak (NPWP) dan berdomisili di wilayah KPP Pratama Jakarta Setiabudi IV. Jumlah Wajib Pajak orang pribadi yang terdaftar sampai dengan Desember 2019 adalah sebanyak 58,752 dengan sampel minimal sebanyak 96. Peneliti telah menyebarkan sebanyak 200 kuesioner dengan kuesioner yang kembali sebanyak 143 kuesioner dan yang dapat diolah adalah sebesar 112 kuisioner.

Tabel 1 Klasifikasi Responden berdasarkan Jenis Kelamin

\begin{tabular}{|c|c|c|c|}
\hline No. & Jenis Kelamin & Jumlah Responden & Presentase $\%$ \\
\hline 1. & Perempuan & 34 & $30 \%$ \\
\hline 2. & Laki-Laki & 78 & $70 \%$ \\
\hline & Jumlah & 112 & $100 \%$ \\
\hline
\end{tabular}

Sumber:Data Primer, Diolah 2020

Tabel 2 Klasifikasi Responden berdasarkan Penghasilan

\begin{tabular}{|c|c|c|c|}
\hline No & Penghasilan & Jumlah Responden & Presentase $\%$ \\
\hline 1 & $\operatorname{Rp~500.000-Rp~2.900.000~}$ & 47 Responden & $42 \%$ \\
\hline 2 & $\operatorname{Rp~3.000.000~-~Rp~5.000.000~}$ & 34 Responden & $30 \%$ \\
\hline 3 & Rp 7.100.000 - Rp 10.000.000 & 31 Responden & $28 \%$ \\
\hline \multicolumn{2}{|l}{ Jumlah } & 112 Responden & $100 \%$ \\
\hline
\end{tabular}

Sumber: Data Primer, Diolah 2020

Tabel 3 Klasifikasi Responden Berdasarkan Umur

\begin{tabular}{|l|l|l|l|}
\hline No. & \multicolumn{1}{|c|}{ Umur } & Jumlah Responden & Presentase $\%$ \\
\hline 1. & $17-25$ Tahun & 52 Responden & $46 \%$ \\
\hline 2. & $26-35$ Tahun & 31 Responden & $28 \%$ \\
\hline 3. & $36-50$ Tahun & 22 Responden & $20 \%$ \\
\hline 4. & $>50$ Tahun & 7 Responden & $6 \%$ \\
\hline & Jumlah & 112 Responden & $100 \%$ \\
\hline
\end{tabular}

Sumber:Data Primer, Diolah 2020

Tabel 4 Klasifikasi Responden Berdasarkan Pekerjaan

\begin{tabular}{|c|c|c|c|}
\hline No & Pekerjaan & Jumlah Responden & Persentase \\
\hline 1 & Mahasiswa & 43 Responden & $38 \%$ \\
\hline 2 & Karyawan Swasta & 31 Responden & $28 \%$ \\
\hline 3 & PNS & 16 Responden & $14 \%$ \\
\hline 4 & Wirausaha & 2 Responden & $2 \%$ \\
\hline 5 & Lain nya & 20 Responden & $18 \%$ \\
\hline \multicolumn{2}{|l}{ Jumlah } & 112 Responden & $100 \%$ \\
\hline
\end{tabular}

Sumber : Data Primer, Diolah 2020 
Tabel 5 Klasifikasi Responden Berdasarkan Pendidikan

\begin{tabular}{|c|c|c|c|}
\hline No & Pendidikan & Jumlah Responden & Persentase \\
\hline 1 & $\begin{array}{c}\text { SMA / SMK / MA } \\
\text { Sederajat }\end{array}$ & 54 Responden & $48 \%$ \\
\hline 2 & Diploma & 4 Responden & $4 \%$ \\
\hline 3 & Sarjana & 54 Responden & $48 \%$ \\
\hline \multicolumn{2}{|c|}{ Jumlah } & 112 Responden & $100 \%$ \\
\hline
\end{tabular}

Sumber : Data Primer, Diolah 2020

Hasil Analisis Deskriptif Jawaban responden

Tabel 6 Analisis Deskriptif Jawaban Responden

\begin{tabular}{|c|c|c|c|c|c|c|c|c|c|}
\hline Variabel & \multicolumn{3}{|c|}{ Distribusi Jawaban (\%) } & Min & Max & Rata- & \multicolumn{3}{c|}{ Standar } \\
\cline { 2 - 10 } & 1 & 2 & 3 & 4 & 5 & & & Rata & Deviasi \\
\hline $\begin{array}{c}\text { Kepatuhan Wajib } \\
\text { Pajak Orang Pribadi }\end{array}$ & 3.41 & 8.87 & 21.33 & 44.11 & 22.28 & 8 & 40 & 30.21 & 5,326 \\
\hline Kebijakan Efilling & 0.26 & 3.01 & 24.05 & 50.10 & 22.58 & 17 & 35 & 27.41 & 3.878 \\
\hline Sanksi Perpajakan & 3.52 & 8.76 & 21.13 & 44.31 & 22.28 & 11 & 25 & 18.82 & 2.997 \\
\hline Kesadaran wajib pajak & 2.53 & 4.43 & 27.09 & 46.15 & 19.59 & 6 & 30 & 22.53 & 3.903 \\
\hline
\end{tabular}

Sumber: Data primer diolah 2020

\begin{tabular}{|c|c|c|c|c|}
\hline \multicolumn{5}{|c|}{ Tabel 7 Hasil Uji Validitas } \\
\hline Variabel & No Pertanyaan & R-Hitung & $>/<$ & R-Tabel \\
\hline \multirow{4}{*}{$\begin{array}{l}\text { Kebijakan } E \text { - } \\
\quad \text { Filing }\end{array}$} & 1 & 0,960 & $>$ & 0,361 \\
\hline & 2 & 0.944 & $>$ & 0,361 \\
\hline & 3 & 0,965 & $>$ & 0,361 \\
\hline & 4 & 0,947 & $>$ & 0,361 \\
\hline \multirow{2}{*}{ ( X 1 ) } & 5 & 0,903 & $>$ & 0,361 \\
\hline & 6 & 0,893 & $>$ & 0,361 \\
\hline \multirow{4}{*}{ Sanksi Perpajakan } & 1 & 0,937 & $>$ & 0,361 \\
\hline & 2 & 0,959 & $>$ & 0,361 \\
\hline & 3 & 0,955 & $>$ & 0,361 \\
\hline & 4 & 0,947 & $>$ & 0,361 \\
\hline \multirow{2}{*}{$\begin{array}{c}\text { Kesadaran Wajib } \\
\text { Pajak }\end{array}$} & 1 & 0,917 & $>$ & 0,361 \\
\hline & 2 & 0,972 & $>$ & 0,361 \\
\hline \multirow{3}{*}{ ( X 3 ) } & 3 & 0,954 & $>$ & 0,361 \\
\hline & 4 & 0,967 & $>$ & 0,361 \\
\hline & 5 & 0,900 & $>$ & 0,361 \\
\hline \multirow{6}{*}{$\begin{array}{c}\text { Kepatuhan Wajib } \\
\text { Pajak }\end{array}$} & 1 & 0,937 & $>$ & 0,361 \\
\hline & 2 & 0,933 & $>$ & 0,361 \\
\hline & 3 & 0,958 & $>$ & 0,361 \\
\hline & 4 & 0,975 & $>$ & 0,361 \\
\hline & 5 & 0,932 & $>$ & 0,361 \\
\hline & 6 & 0,956 & $>$ & 0,361 \\
\hline
\end{tabular}

Sumber Data Primer Diolah

Berdasarkan tabel 6 diketahui bahwa distribusi jawaban responden mengenai sistem kepatuhan wajib pajak orang pribadi dari yang tertinggi hingga yang terendah adalah sebagai berikut: setuju (44,11\%), sangat setuju (22,28\%), netral $(21,33 \%)$, tidak setuju $(8,87 \%)$ dan sangat tidak setuju $(3,41 \%)$. Urutan yang tertinggi hingga yang terendah mengenai kebijakan EFilling sebagai berikut: setuju (50,10\%), netral $(24,05 \%)$, sangat setuju (22,58\%), tidak setuju (3,01\%) dan tidak setuju (0,26\%). Urutan yang tertinggi hingga yang terendah mengenai sanksi perpajakan adalah sebagai berikut: setuju $(44,31 \%)$, sangat setuju $(22,28 \%)$, netral $(21,13 \%)$, tidak setuju $(8,76 \%)$ dan sangat tidak setuju $(3,51 \%)$. Sedangkan urutan yang tertinggi hingga terendah mengenai kesadaran wajib pajak adalah sebagai berikut : setuju (46,15\%), netral $(27,09 \%)$, sangat setuju $(19,59 \%)$, tidak setuju $(4,43 \%)$ dan sangat tidak setuju $(2,53 \%)$. 
Taxpayer

Compliance and

Tax Policies

\section{6}

\section{Uji Asumsi dan Kualitas Data Penelitian}

Hasil Pengujian Validitas Instrumen disajikan dalam Tabel 7. Dalam penelitian, suatu variabel dikatakan cukup reliabilitas bila variabel tersebut mempunyai nilai construk reliability lebih besar dari 0,6. Namun, untuk penelitian tahap awal nilai cronbachs alpha lebih dari 0,5 dianggap mempunyai reliabilitas yang baik (Wati, 2018).

Tabel 8 Nilai Composite Reliability dan Cronbachs Alpha

\begin{tabular}{|c|c|c|}
\hline Variabel & $\begin{array}{c}\text { Composite } \\
\text { Reliability }\end{array}$ & $\begin{array}{c}\text { Cronbachs } \\
\text { Alpha }\end{array}$ \\
\hline Kebijakan E-Filing & 0,977 & 0,971 \\
\hline Sanksi Perpajakan & 0,973 & 0,964 \\
\hline Kesadaran Wajib Pajak & 0,975 & 0,968 \\
\hline Kepatuhan Wajib Pajak & 0,978 & 0,982 \\
\hline
\end{tabular}

Sumber : Hasil Penelitian, 2020

Evaluasi goodness of fit model penelitian diukur dengan menggunakan nilai R-Square (R2). Inner Model menggambarkan hubungan antar variabel laten berdasarkan substantive theory.

Tabel $9 R$-Square

\begin{tabular}{|c|c|c|}
\hline Konstruk & $R$-Square & $R$-Square Adjusted \\
\hline Kepatuhan Wajib Pajak & 0,909 & 0,903 \\
\hline
\end{tabular}

Sumber : Hasil Penelitian, 2020

Tabel 10 Result Of Inner Weight

\begin{tabular}{|c|c|c|c|c|c|}
\hline Konstruk & $\begin{array}{c}\text { Sampel } \\
\text { Asli (O) }\end{array}$ & $\begin{array}{c}\text { Sampel } \\
\text { Mean (M) }\end{array}$ & $\begin{array}{c}\text { Standard } \\
\text { Deviasi } \\
\text { (STDEV) }\end{array}$ & $\begin{array}{c}\text { T-Statistik } \\
(\mid \mathbf{O} / \text { STDEV|) }\end{array}$ & Pvalues \\
\hline $\begin{array}{c}\text { Kebijakan E- Filing } \\
\text { > Kepatuhan } \\
\text { Wajib Pajak }\end{array}$ & 0,344 & 0,348 & 0,164 & 2.101 & 0,036 \\
\hline $\begin{array}{c}\text { Sanksi Perpajakan } \\
\text { > Kepatuhan } \\
\text { Wajib Pajak }\end{array}$ & $-0,114$ & $-0,109$ & 0,148 & 0,769 & 0,442 \\
\hline $\begin{array}{c}\text { Kesadaran Wajib } \\
\text { Pajak > Kepatuhan } \\
\text { Wajib Pajak }\end{array}$ & 0,742 & 0,733 & 0,135 & 5.504 & 0,000 \\
\hline
\end{tabular}

Sumber : Hasil Penelitian, 2020

Berdasarkan tabel 10 diperoleh nilai t-statistik sebesar 2.101 yang lebih besar dari $\mathrm{T}$ tabel $1.67591(2.101>1.67591)$. Nilai Probabilitas yang dihasilkan sebesar 0.036 lebih kecil dari nilai signifikansi yang telah ditentukan yaitu 0.05 yang berarti variabel Kebijakan E-Filing berpengaruh positif signifikan terhadap Kepatuhan Wajib Pajak. Nilai original sample of estimate adalah positif yaitu 0.344 . Dari hasil ini dapat disimpulkan bahwa Kebijakan E-Filing berpengaruh Positif signifikan terhadap Kepatuhan Wajib Pajak. Dengan demikian, Hipotesis 1 yang menyatakan bahwa Kebijakan E-Filing berpengaruh positif signifikan terhadap Kepatuhan Wajib Pajak Diterima.

Berdasarkan tabel 10 diperoleh nilai t-statistik sebesar 0,769 yang lebih kecil dari Ttabel $1.67591(0,769<1.67591)$. Nilai Probabilitas yang dihasilkan sebesar 0,442 lebih besar dari nilai signifikansi yang telah ditentukan yaitu 0.05 yang berarti variabel Sanksi Perpajakan tidak berpengaruh terhadap Kepatuhan Wajib Pajak. Nilai original sample of estimate adalah negatif yaitu -0.114. Dari hasil ini dapat disimpulkan bahwa Sanksi Perpajakan tidak berpengaruh terhadap Kepatuhan Wajib Pajak. Dengan demikian, Hipotesis 2 yang menyatakan bahwa Sanksi Perpajakan tidak berpengaruh terhadap Kepatuhan Wajib Pajak Ditolak.

Berdasarkan tabel 10 diperoleh nilai T-statistik sebesar 5.504 yang lebih kecil dari Ttabel $1.67591(5.504<1,67591)$. Nilai Probabilitas yang dihasilkan sebesar 0.000 lebih kecil dari nilai signifikansi yang telah ditentukan yaitu 0.05 yang berarti variabel Kesadaran Wajib Pajak Berpengaruh terhadap Kepatuhan Wajib Pajak. Nilai original 
sample of estimate adalah positif yaitu 0.742 . Dari hasil ini dapat disimpulkan bahwa Kesadaran Wajib Pajak Berpengaruh terhadap Kepatuhan Wajib Pajak. Dengan demikian, Hipotesis 3 yang menyatakan bahwa Kesadaran Wajib Pajak Berpengaruh terhadap Kepatuhan Wajib Pajak Diterima.

\section{Pembahasan}

Hasil penelitian yang dilakukan oleh Suherman, Almunawaroh, dan Marliana (2015) menunjukkan bahwa e-filing berpengaruh Positif terhadap Kepatuhan Wajib Pajak. Hasil pengujian terdapat hipotesis diterima. Disimpulkannya bahwa semakin tingginya Kebijakan E-Filing diterapkan di KPP Setiabudi IV maka semakin tinggi juga Kepatuhan Wajib Pajak karena semakin banyak Wajib Pajak yang mengikuti Kebijakan E-Filing di KPP Setiabudi IV akan meningkatkan Kepatuhan Wajib Pajak. Dengan adanya Kebijakan E-Filing memudahkan Wajib Pajak untuk melaporkan SPT setiap tahun nya dan lebih menghemat biaya, serta tenaga.

Hasil Penelitian Winerungan (2017) yang menyatakan Sanksi Perpajakan berpengaruh Negatift terhadap Kepatuhan Wajib Pajak. Hasil pengujian terhadap hipotesis ditolak. Disimpulkannya bahwa Sanksi Perpajakan untuk meningkatkan Kepatuhan Wajib pajak namun pada hasil penelitian berbanding terbalik, Sanksi Perpajakan tidak berpengaruh Kepatuhan Wajib Pajak di KPP Setiabudi IV, masih banyak Wajib Pajak yang menghiraukan adanya Sanksi Perpajakan dan masih banyak Wajib Pajak yang diberikan Sanksi karna tidak Melaporkan SPT tepat waktu.

Hasil Penelitian Jatmiko (2016), Kesadaran Wajib Pajak atas kebijakan perpajakan sebagai pembiayaan negara sangat diperlukan untuk meningkatkan Kepatuhan Wajib Pajak. Hasil Penelitian Muliari dan Nugroho (2016) semakin tinggi tingkat Kesadaran Wajib Pajak maka pamahaman dan pelaksanaan kewajiban perpajakan semakin baik sehingga dapat meningkatkan kepatuhan. Pentingnya suatu kesadaran untuk membayar pajak sangat diperlukan, mengingat tingginya kepentingan pajak bagi Negara diwajibkan untuk Wajib Pajak sadar dalam membayar pajak. Jadi Semakin tinggi suatu Kesadaran Wajib Pajak dalam membayar pajak, maka rasa kesadaran akan tinggi dalam mematuhi membayar pajak.

\section{PENUTUP}

Hipotesis pertama menunjukkan bahwa Kebijakan E- Filing berpengaruh positif terhadap Kepatuhan Wajib Pajak. Hipotesis kedua bahwa sanksi perpajakan tidak berpengaruh terhadap kepatuhan wajip pajak orang pribadi Hipotesis ketiga kesadaran wajib pajak orang pribadi berpengaruh terhadap kepatuhan wajib pajak orang pribadi. Hasil pengujian terdapat hipotesis diterima. Disimpulkannya bahwa semakin tingginya Kebijakan E-Filing diterapkan di KPP Setiabudi IV maka semakin tinggi juga Kepatuhan Wajib Pajak karena semakin banyak Wajib Pajak yang mengikuti Kebijakan E-Filing di KPP Setiabudi IV akan meningkatkan Kepatuhan Wajib Pajak. Dengan adanya Kebijakan E-Filing memudahkan Wajib Pajak untuk melaporkan SPT setiap ahun nya dan lebih menghemat biaya, serta tenaga.

Hasil pengujian terhadap hipotesis ditolak. Disimpulkannya bahwa Sanksi Perpajakan untuk meningkatkan Kepatuhan Wajib pajak namun pada hasil penelitian berbanding terbalik, Sanksi Perpajakan tidak berpengaruh Kepatuhan Wajib Pajak di KPP Setiabudi IV, masih banyak Wajib Pajak yang menghiraukan adanya Sanksi Perpajakan dan masih banyak Wajib Pajak yang diberikan Sanksi karna tidak Melaporkan SPT tepat waktu. Hasil pengujian terhadap hipotesis diterima, disimpulkan bahwa kesadaran wajib pajak orang pribadi semakin tinggi maka pamahaman dan pelaksanaan kewajiban perpajakan semakin baik sehingga meningkatkan kepatuhan. Pentingnya suatu kesadaran untuk membayar pajak sangat diperlukan, mengingat tingginya kepentingan pajak bagi Negara diwajibkan untuk Wajib Pajak sadar dalam membayar pajak. Jadi Semakin tinggi suatu Kesadaran Wajib Pajak dalam membayar pajak, maka rasa kesadaran akan tinggi dalam mematuhi membayar pajak.
Compliance and

Tax Policies

207 
Taxpayer

Compliance and

Tax Policies
DAFTAR PUSTAKA

Agustiningsih, Isroah (2016) Jurnal Nominal, Pengaruh Penerapan E-Filling, Tingkat Pemahaman Perpajakan dan Kesadaran Wajib Pajak Terhadap Kepatuhan Wajib Pajak di KPP Pratama Yogyakarta, Jurnal Nominal,

Damanik, D. N. (2020). Analisis Penggunaan E-Filling untuk peningkatan Kepatuha Wajib Pajak, Jurnal Perpajakan 1(2), 19-27.

HIDAYAT, T. (2019). Pengaruh Penerapan E-Filling dan Sanksi Perpajakan Terhadap Kepatuhan Wajib Pajak Orang Pribadi (Studi kasus pada WPOP Berstatus mahasiswa FEB Di Universitas Mercu Buana kelas Regular 2 yang memiliki NPWP) (Doctoral dissertation, Universitas Mercu Buana Jakarta).

Indriyani, N., \& Askandar, N. S. (2018). Pengaruh Kualitas Pelayanan, Sanksi Perpajakan, Biaya-biaya Kepatuhan Pajak Dan Penerapan E-Filing Pada Kepatuhan Wajib Pajak (Studi Kasus Di Desa Sengguruh Kecamatan Kepanjen Kabupaten Malang). Jurnal Ilmiah Riset Akuntansi, 7(07).

Nuraina, F. S. E. (2017). Pengaruh sanksi perpajakan terhadap kepatuhan wajib pajak

Lina Nurlela (2018). Pengaruh Penerapan E-Filing Terhadap Kepatuhan Wajib Pajak Pada KPP Pratama Garut, Jurnal Akuntansi Wahana.

Murdihardjo, L., Nurjanah, Y., \& Rendy, R. (2020, May). Implementing INTACS Dynamics Enterprise Resources Planning System for Financial Statements. In 2nd International Seminar on Business, Economics, Social Science and Technology (ISBEST 2019) (pp. 228-233). Atlantis Press.

Orang pribadi di Kantor Pelayanan Pajak Pratama Madiun. EQUILIBRIUM: Jurnal Ilmiah Ekonomi dan Pembelajarannya, 5(1), 45-55.

Patricia, M. B. S. (2017). Pengaruh Kesadaran Wajib Pajak Dan Penerapan E-Filing Terhadap Kepatuhan Wajib Pajak (Studi Pada UMKM Yang Terdaftar di KPP Pratama Candisari Semarang) (Doctoral dissertation, Diponegoro University).

Purba, J. H. V. (2020). Does Chinese Vegetable Oil Consumption Have Positive Implications for the Indonesia-China Trade Balance?. Integrated Journal of Business and Economics, 4(1), 36-44.

Putri, K. J., \& Setiawan, P. E. (2017). Pengaruh Kesadaran, Pengetahuan Dan Pemahaman Perpajakan, Kualitas Pelayanan Dan Sanksi Perpajakan Terhadap Kepatuhan Wajib Pajak. E-Jurnal Akuntansi Universitas Udayana, 18(2), 11121140.

Rusdiyana, R., \& Munawar, A. (2012). ANALISIS PENGELOLAAN AKTIVA TERHADAP KINERJA PENDAPATAN PER LEMBAR SAHAM (EPS). Jurnal Online Mahasiswa-Manajemen, 1(2).

Sari, D. P., Putra, R. B., Fitri, H., Ramadhanu, A., \& Putri, F. C. (2019). Pengaruh Pemahaman Pajak, Pelayanan Aparat Pajak, Sanksi Perpajakan dan Preferensi Risiko Perpajakan terhadap Kepatuhan Wajib Pajak (Studi Kasus UMKM Toko Elektronik di Kecamatan Sitiung Dharmasraya). Jurnal Teknologi Dan Sistem Informasi Bisnis, 1(2), 18-22.

Solekhah, P., \& Supriono, S. (2018). Pengaruh Penerapan Sistem E-Filing, Pemahaman Perpajakan, Kesadaran Wajib Pajak dan Sanksi Perpajakan Terhadap Kepatuhan Wajib Pajak Orang Pribadi di KPP Pratama Purworejo. Journal of Economic, Management, Accounting and Technology, 1(1), 74-90.

Susmita, P. R., \& Supadmi, N. L. (2016). Pengaruh kualitas pelayanan, sanksi Perpajakan, biaya kepatuhan pajak, dan penerapan e-filing pada kepatuhan Wajib Pajak. E- Jurnal Akuntansi, 1239-1269. 